\title{
Identifying knowledge gaps in seagrass research and management: an Australian perspective
}

\section{Authors}

4 Paul H. York ${ }^{1 *}$, Timothy M. Smith², Rob G. Coles ${ }^{1}$, Skye A. McKenna ${ }^{1}$, Rod M. Connolly ${ }^{3}$, Andrew

5 D. Irving ${ }^{4}$, Emma L. Jackson4, Kathryn McMahon', John W. Runcie', Craig D. H. Sherman², Brooke

6 K. Sullivan ${ }^{7}$, Stacy M. Trevathan-Tackett ${ }^{8}$, Kasper E. Brodersen ${ }^{8}$, Alex B. Carter ${ }^{1}$, Carolyn J.

7 Ewers $^{2}$, Paul S. Lavery 5 , Chris M. Roelfsema ${ }^{9}$, Elizabeth A. Sinclair ${ }^{10}$, Simone Strydom ${ }^{5}$, Jason E.

8 Tanner ${ }^{11,12}$, Kor-jent van Dijk ${ }^{12}$, Fiona Y. Warry ${ }^{13}$, Michelle Waycott ${ }^{12}$, Sam Whitehead ${ }^{14}$

$9 \quad{ }^{1}$ Centre for Tropical Water and Aquatic Ecosystem Research (TropWATER), James Cook University, QLD, Australia, ${ }^{2}$ Centre for Integrative Ecology, School of Life and Environmental Sciences, Deakin University, VIC, Australia, ${ }^{3}$ Australian Rivers Institute - Coast and Estuaries, School of Environment, Griffith University, QLD, Australia, ${ }^{4}$ School of Medical and Applied Sciences, Central Queensland University, QLD, Australia, ${ }^{5}$ School of Science and Centre for Marine Ecosystems Research, Edith Cowan University, WA, Australia, ${ }^{6}$ School of Life and Environmental Sciences, University of Sydney, NSW, Australia, ${ }^{7}$ School of BioSciences, University of Melbourne, VIC, Australia, ${ }^{8}$ Plant Functional Biology and Climate Change Cluster (C3), University of Technology Sydney, NSW, Australia, ${ }^{9}$ Remote Sensing Research Center, School of Geography, Planning and Environmental Management, University of Queensland, QLD, Australia, ${ }^{10}$ School of Plant Biology and Oceans Institute, University of Western Australia, WA, Australia, ${ }^{11}$ South Australian Research and Development Institute, SA, Australia, ${ }^{12}$ University of Adelaide, SA, Australia, ${ }^{13}$ School of Chemistry, Monash University, VIC, Australia, ${ }^{14}$ Derwent Estuary Program, TAS, Australia

Acknowledgements: We would like to acknowledge attendees to the workshop that provided valuable input into the review; Mat Adams, Linda Avery, Marion Cambridge, Timothy Coggan, Catherine Collier, Carol Conacher, Peter Davey, Suzanna Evans, Jennita Gay, Sharyn Hickey, Victoria Hrebien, Gary Kendrick, Kieryn Kilminster, Hugh Kirkman, Peter Macreadie, Bojana Manojlovic, Peggy O’Donnell, Greg Parry, Mathieu Pernice, Jeff Shimeta, Jimena SamperVillarreal, Richard Stafford-Bell, Jonathon Stevens, Alexandra Thomson and Samantha Tol, as well as Ivan Nagelkerken, Kate O'Brien and Michael Rasheed who provided valuable input in the form of questions and advice prior to the workshop but were unable to attend. The Centre for Tropical Water and Aquatic Ecosystem Research (TropWATER) at James Cook University provided financial support to run the workshop, Deakin University provided the facilities and the Australian Marine Science Association provided organisational support to assist in coordinating the workshop.

Contributors: PHY, TMS, RGC and SAM organized and ran the workshop and led the writing of the manuscript. RGC, SAM, RMC, ADI, ELJ, KM, JWR, CDHS, BKS and SMT facilitated discussion and coordinated the composition of questions from each field of research group. All authors attended the workshop, contributed to discussion of research questions, contributed to the writing of the manuscript and approved the final article. 
51

52

53

\section{Highlights}

- We provide a strategic review of research gaps for Australian seagrass ecosystems

- Priorities areas were identified at a workshop of seagrass experts

- Forty key knowledge gaps were identified across ten research fields

- This review provides a platform for a coordinated approach to seagrass research and management

\section{Abstract}

Seagrass species form important marine and estuarine habitats providing valuable ecosystem services and functions. Coastal zones that are increasingly impacted by anthropogenic development have experienced substantial declines in seagrass abundance around the world. Australia, which has some of the world's largest seagrass meadows and is home to over half of the known species, is not immune to these losses. In 1999 a review of seagrass ecosystems knowledge was conducted in Australia and strategic research priorities were developed to provide research direction for future studies and management. Subsequent rapid evolution of seagrass research and scientific methods has led to more than $70 \%$ of peer reviewed seagrass literature being produced since that time. A workshop was held as part of the Australian Marine Sciences Association conference in July 2015 in Geelong, Victoria, to update and redefine strategic priorities in seagrass research. Participants identified 40 research questions from 10 research fields (taxonomy and systematics, physiology, population biology, sediment biogeochemistry and microbiology, ecosystem function, faunal habitats, threats, rehabilitation and restoration, mapping and monitoring, management tools) as priorities for future research on Australian seagrasses. Progress in research will rely on advances in areas such as remote sensing, genomic tools, microsensors, computer modeling, and statistical analyses. A more interdisciplinary approach will be needed to facilitate greater understanding of the complex interactions among seagrasses and their environment. 


\section{INTRODUCTION}

Seagrasses are marine flowering plants that provide one of the most productive habitats on earth. Seagrasses support a wide array of ecosystem functions and services including nutrient cycling and particle trapping that improves water quality, stabilization of sediments, provision of food for many associated faunal species including waterfowl, dugong and turtles, the capture and storage of carbon, and the creation of habitat for animals facilitating biodiversity (Barbier et al., 2011; Costanza et al., 2014; Orth et al., 2006). The global extent of seagrass ecosystems is declining at an alarming rate, with a reduction of approximately $30 \%$ of the world's seagrass distribution post the industrial revolution (Waycott et al., 2009). Declines from anthropogenic pressures such as eutrophication, coastal and port developments are expected to continue and climate change threats are predicted to increase. Focused efforts on more effective science based conservation, monitoring, restoration and management of seagrass ecosystems are required (Kilminster et al., 2015; Orth et al., 2006; Unsworth et al., 2015).

A large portion of the planet's known seagrass meadows occur in Australian waters (Green and Short, 2003); incorporating half (37) of the world's 72 species (Kilminster et al., 2015; Short et al., 2011), and two of the five hotspots of global seagrass diversity in northern Australia (including the Great Barrier Reef) and south-western Australia (Short et al., 2007). Seagrasses in Australia face the same threats identified as major global threats, such as agricultural, urban and industrial runoff, coastal and port developments, disease and climate change (Ghorai and Sen, 2015; Grech et al., 2012; Grech et al., 2011; Short and Neckles, 1999; Sullivan et al., 2013). These threats have led to declines in Australian seagrass, with temperate systems tracking similar to global averages (Waycott et al., 2009), and recent large scale declines in tropical Queensland (e.g., McKenna et al., 2015). This has prompted actions that put Australia at the forefront of efforts to improve management and conservation outcomes (Coles et al., 2015; Kilminster et al., 2015).

Globally, seagrass research began to take off in the early 1970s, with the first review of Australian seagrass research occurring shortly after (Larkum, 1977). Since then a series of books have periodically synthesized and updated the growing knowledge on seagrass ecology both internationally (e.g., den Hartog, 1970; Hemminga and Duarte, 2000; Larkum et al., 2006) and focusing on Australia (Larkum et al., 1989). Publications on global seagrass distribution (Green and Short, 2003) and research methods (Short and Coles, 2001) have arisen from a series of biennial global seagrass workshops dating back to 1993 (Coles et al., 2014). Australia has traditionally been a large contributor to global seagrass research, producing close to one fifth of total peer reviewed literature; second to the USA (Figure 1a). While research has generally been carried out on an ad-hoc basis, a strategic review of seagrass knowledge gaps in Australia with recommendations for future research was published just before the turn of the century (Butler and Jernakoff, 1999) when approaches to seagrass ecology were still developing and were dominated by descriptive studies (Duarte, 1999). This review brought together expert working groups to focus on gaps in understanding around seagrass ecosystem function, links between seagrass habitat and fisheries, monitoring and assessment, remediation and restoration and management (Butler and Jernakoff, 1999). In the decade and a half since this review, almost 75 percent of the peer-reviewed seagrass literature globally, and 72 percent from Australia, has been published (Figure 1b). 
In light of this huge increase in seagrass knowledge, Australian seagrass scientists came together at the Australian Marine Sciences Association Annual Conference in Geelong, Victoria to review progress in understanding the components of seagrass systems (fields of research) and in documenting weaknesses and gaps that need to be addressed. In this paper, we revisit the work of Butler and Jernakoff (1999) to elicit an updated set of questions across a broad range of seagrass research fields that, if addressed, will increase our understanding of seagrass ecosystems and fill current knowledge gaps in seagrass research in Australia. These questions are also of great relevance to seagrass research in a global context.
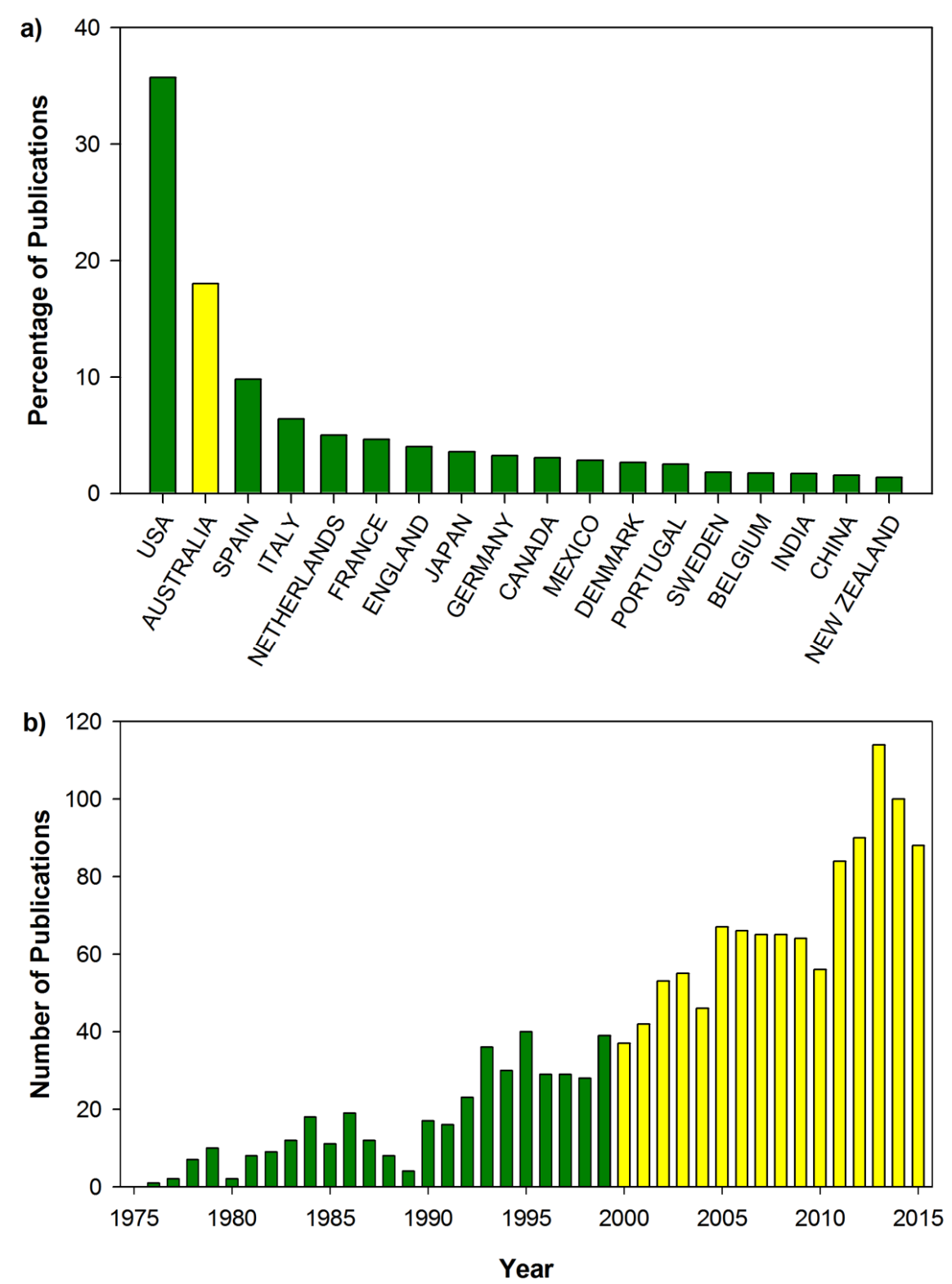
Figure 1: Summary of peer-reviewed seagrass literature showing a) percentage of publications per yellow columns indicating publications since the last strategic review of seagrass was published in Australia in 1999. (Data sourced on 23/12/2015 from Thomson Reuters, Web of Science using the search term "seagrass" and then analysing results by "Countries/Territories". The publications affiliated with Australia were then analysed by "Publication Years"). 
A workshop to assemble data on gaps in seagrass research was held as part of the Australian Marine Sciences Association Annual Conference in July 2015 in Geelong, Victoria. This conference included leading marine scientists from around Australia. We followed similar protocols used previously for soliciting the opinions of experts in the fields of review (Hays et al., 2016; Sutherland et al., 2013; Wilson et al., 2010). Open invitations were sent to experts in a range of seagrass research fields targeted to be inclusive of all major seagrass research groups in Australia. Invitees who had indicated they would participate were encouraged to submit three questions in their field(s) of expert knowledge. These questions were to illicit important and feasible research questions or address management problems covering major knowledge gaps for that field.

Responses were compiled into 10 research fields covering the broad suite of research conducted on seagrass ecosystems in Australia. These were: taxonomy and systematics; physiology; population biology; sediment biogeochemistry and microbiology; ecosystem function; faunal habitats; threats; rehabilitation and restoration; mapping and monitoring, management tools. Prior to the workshop, the invitation process resulted in 172 research questions across all fields. The number of questions in each field ranged from three in seagrass sediment and microbiology to 31 in ecosystem function. The questions were used as the basis for discussion during the workshop, where participants were organized in groups representing research fields matching their expertise and each group was facilitated by a nominated coordinator. Groups discussed the status of research within their field, noting topics that were well researched and others where critical knowledge gaps remained. Using this information and the list of questions submitted for their topic they developed three to five broad research questions for their field encompassing the major knowledge gaps identified. Groups also discussed potential new technologies, methods and analytical tools that could be used to assist in answering these questions. The output of this process has not been ranked in any order of importance but has been presented in categories beginning with those relating to individual plants and species, followed by more complex ecosystem interactions and culminating in monitoring, management and restoration.

159 The workshop was attended by 49 participants representing all six Australian states, from government, university and private research institutions. They included representatives from all the major institutions with seagrass research laboratories (Supplementary Table 1 for attendees, affiliations and research fields). There was a broad historical background amongst participants who have studied seagrass across many geographical regions encompassing all the major seagrass groups and habitats in Australia dating back to the 1970's. The workshop included five scientists who had contributed to the 1999 review.

\section{RESULTS}

Questions addressing gaps and weaknesses in Australia's seagrass research knowledge

170 1. How many species of seagrass grow in Australian waters? The Australian Plant Name

171 Index (APNI) maintains a comprehensive list of vascular plant species in Australia (McNeil, 
2015). However, there is an ongoing process of (re-)defining taxonomic concepts for species and different interpretations of available information which question the current taxonomic status of seagrass species, such as the Zostera/Heterozostera debate (see Coyer et al., 2013; Jacobs and Les, 2009; Kuo, 2005). Resolving seagrass species identification is critical for seagrass research and to ensure competent experimental design.

\section{Do we need a better species concept for Australian seagrasses? Seagrasses display a high} level of phenotypic plasticity (Backman, 1991; Kuo and Den Hartog, 2001), and there are several seagrass species that might be considered 'cryptic,' being genetically or morphologically indistinguishable (Waycott et al., 2006). With the increasing availability and decreasing costs of advanced genetic studies, there is a sense that we may be recognizing seagrass species diversity where it does not exist or missing diversity where it does exist due to the reduced morphological characters of the plants. The link between morphology, evolution, adaptation and phylogeny at different scales needs to be resolved to answer this question.

\section{How can we increase awareness about the importance and usefulness of taxonomy for} the science community and for the general population? Taxonomy plays an invaluable role in understanding biodiversity and conservation of plant species. Despite this there is a wellrecognized lack of botanical taxonomists, creating a taxonomic bottleneck and preventing the accumulation of reliable site-specific community composition data for critical ecological studies (Callmander et al., 2005; Kim and Byrne, 2006). We need to encourage and support scientists and students who express an interest in taxonomic and systematic studies.

\section{REPRODUCTION, DISPERSAL, RECRUITMENT AND LOCAL ADAPTATION}

\section{How do seagrass reproductive strategies vary through space and time? Asexual} reproduction has long been considered the most important strategy for maintaining seagrass meadows. There is growing evidence that sexual reproduction may be more important in maintaining meadows than previous appreciated (e.g., Jones et al., 2008; Sinclair et al., 2014b), however, outcrossing rates have only been estimated for one Australian species to date (Sinclair et al., 2014a) so this remains a significant gap. We need to know how flowering and seed production varies across a species range and what environmental factors cause variation in annual reproductive investment. There is a need to identify triggers for floral development, pollen release and seed germination. The frequency and extent of hybridisation is not known, with speculation regarding the presence or absence of reproductive barriers (Sinclair et al., 2016).

\section{What role do pollen, seeds and vegetative fragments play in gene flow and population} connectivity? Knowledge of the dispersal potential of pollen, seeds, and clonal (vegetative) propagules remains poor for most species, although there has been significant progress in synthesizing current knowledge of connectivity (e.g., Kendrick et al., 2012; Sinclair et al., 2014b) and in providing the theoretical and conceptual framework for understanding movement ecology of seagrasses (McMahon et al., 2014). There is a requirement for a better understanding of patterns of connectivity and dispersal at local and regional scales for temperate and tropical species to improve marine conservation planning.

\section{What conditions favour recruitment of sexual and asexual propagules? Considerable} variation exists in the time vegetative fragments and seeds (dormant and non-dormant) remain 
viable and the local conditions that favour establishment are poorly understood (e.g., McMahon et al., 2014; Thomson et al., 2015). Seedling recruitment success is poorly studied in seagrasses, but generally accepted as being patchy with low long-term survival (Kendrick et al., 2012). An improved understanding of the rate of plant turnover, and the relative contribution of sexual and asexual reproduction in maintaining meadows (Macreadie et al., 2014) can be determined through temporal sampling in short-lived, annual species, but is far more difficult in long-lived perennial species.

\section{What scale does adaptation occur in seagrasses and what are the major selective forces?} The relative importance of phenotypic plasticity versus genetic adaptation in the resilience of seagrass ecosystems remains unknown but is crucial for understanding this process. Genomic and transcriptomic approaches (e.g., Golicz et al., 2015) are important tools for identifying the genes underlying adaptive traits and how they respond to climate change (Verges et al., 2014) and natural and anthropogenic stressors (Maxwell et al., 2014). Understanding the link between seagrass ecophysiology and genomics will help address how seagrass responds to stress associated with rapid change, and potentially improve conservation and restoration outcomes, which have been very poor to date (Statton et al., 2012).

\section{PHYSIOLOGY OF SEAGRASS}

8. What are the effects of the spectral quality of light on seagrasses? Light is essential for seagrass growth and reproduction (Lee et al., 2007; Ralph et al., 2007), however, the importance of spectral quality is less known. We need to understand the role phytochromes and specific wavelengths of light play in determining the activation and deactivation of light-dependent physiological processes (Casal, 2013) and determine whether comparable work done on marine macroalgae and terrestrial plants is useful. Altered spectral quality from leaf epiphyte cover reduces wavelengths of light available for chlorophyll absorption, thus reducing plant growth (Brodersen et al., 2015a). Variation in spectral quality, across instantaneous to seasonal time scales, is likely to elicit varied responses by seagrasses dependent on ecotype (e.g. deep vs. shallow, oceanic vs. estuarine) and should be investigated.

\section{What are the internal biochemical signaling pathways underlying plant function and} reproduction? The transfer of biochemical signals within both above-ground and below-ground seagrass biomass plays a major role in enabling seagrass responses to short- and long-term environment changes, as well as to initiate reproductive processes (e.g. germination of dormant seeds; Orth et al., 2000). We require a greater understanding of the vulnerability of this internal signaling to both natural and anthropogenic stressors.

\section{1}

\section{To what extent is respiration (and photorespiration) regulated in response to the} environment? Distinguishing the energetic requirements of photosynthesis, respiration and photorespiration enables us to understand the capacity of seagrasses to survive in varied light environments (Touchette and Burkholder, 2000). Future research directions could usefully address 1) the capacity for metabolic processes to respond to environmental changes (e.g. turbidity, temperature), 2) the extent that respiration is endogenously controlled, 3) the persistence of seagrasses in low light environments (and whether this is contingent on the capacity to regulate respiration), 4) the extent that energetic requirements can be modified in response to available energetic resource (light, stored compounds), and 5) whether there is an inviolable basal requirement that defines the limits of survival. 
11. What is the role of microbes in seagrass resilience, function and life history? Although there has been some global research on the communities and functions of seagrass-associated bacteria, little work has been performed on Australian taxa, particularly endemic species. In addition to a paucity of data on the epiphytic and endophytic bacteria and eukaryotic microbes associated with Australian seagrasses, there is little information on the roles of these microbes in the seagrass lifecycle, including mediation of disease, seed germination, nutrient mobilization and sediment detoxification (Brodersen et al., 2015b; Crump and Koch, 2008; Panno et al., 2013; Sullivan et al., 2013).

12. How do changing environmental conditions, particularly anthropogenic pressures, an important component of nutrient cycling and carbon sequestration in seagrass meadows (Hansen et al., 2000; Macreadie et al., 2015). Research on the effects of added nutrients, increased temperature, organic matter recalcitrance (resistance to decomposition), plantderived root/rhizome exudates etc., on microbial metabolism is a priority. We also need to further elucidate the potential adverse effects of fine sediment deposits originating from terrestrial environments on seagrass health. Coastal development and run-off increase the loads of these fine sediments which may introduce harmful compounds that bind to sediment particles (e.g. diuron herbicide) and plant pathogens to the seagrass ecosystem.

13. What are the below-ground dynamics influencing seagrass function? Sediments inhabited by seagrass can vary widely in physical structure, geochemistry, microbial assemblages, and infauna composition (Di Maida et al., 2013; Moriarty et al., 1985). How do sediment attributes, both individually and in combination, influence seagrass persistence? Root and rhizome metabolism and biomass allocation influence whole-plant carbon budgets and nutrient absorption (Hemminga, 1998). How do roots and rhizomes influence seagrass response to environmental stressors? How tolerant are seagrasses to variations in $\mathrm{pH}$ ? How is dissolved organic carbon impacted by substrate biogeochemistry?

14. How important are sediment characteristics for successful restoration? Sediment is almost always critical for seagrass growth and persistence, but excessive deposition (turbidity), accumulation (plant burial), erosion, and re-suspension can impair seagrass restoration (Irving et al., 2010; van Keulen et al., 2003). Additionally, understanding the importance of sediment quality, such as organic and nutrient content, grain size distribution, sediment source, porosity, and microbial activity may improve restoration outcomes.

\section{FAUNAL ASSEMBLAGES}

\section{How does herbivory influence the structure and function of seagrass? Studies in} Australia are limited but suggest biogeographic differences in the relative influence of meso-, macro- and megaherbivory on seagrass (Aragones et al., 2006; Cook et al., 2011; Ebrahim et al., 2014; Verhoeven et al., 2012). A better understanding is required of how herbivory affects seagrass biomass and species composition, and how those effects interact with water and plant nutrient concentrations. It is important to know how rates of grazing of seagrass and epiphytic algae promote resilience of seagrass (Maxwell et al., 2015), whether herbivores aid seagrass 
dispersal (via direct transfer or in their faeces), and how those factors will play out under a changing climate.

304

305

306

307

308

309

310

311

312

313

16. What is the effect of seascape on seagrass communities? The spatial arrangement of seagrass patches and their relation to other habitats such as mangroves, saltmarsh, and deeper channels - termed 'seascape' - is important for structuring seagrass faunal communities (Nagelkerken et al., 2015; Smith et al., 2012). However, knowledge of the effect of seascape on the functioning of seagrass habitats and their fauna is generally lacking. Although recent work has demonstrated effects of seascape on cross habitat trophic subsidies (Davis et al., 2014), effects on processes including recruitment, bioenergetics, herbivory and the nursery role of seagrass habitats (Nagelkerken et al., 2015) remain unclear, particularly for deeper seagrass (> $15 \mathrm{~m}$ ). We need stronger predictive capacity of seascape effects for integrated management of coastal resources.

\section{What are the cascading effects of changes in biomass of higher order predators on} faunal assemblages and seagrass structure and function? Changes in biomass of higher trophic levels may result from harvesting of fisheries species and/or altered distributions of prey species (Heithaus et al., 2009), and their effect on seagrass habitats and fauna are likely to vary enormously depending on the strength of interaction and number of trophic levels involved (Huijbers et al., 2015). Cascades might also affect seagrass ecosystem functions (e.g., rates of blue carbon formation, Atwood et al., 2015).

\section{What are the effects of anthropogenic pressures on the structure and function of} seagrass food webs? Anthropogenic pressures, including land use alterations and climate change, will alter the timing and magnitude of terrestrial nutrient delivery to seagrass ecosystems (Gillanders et al., 2011) with potentially large implications for the food webs they support. Altered nutrient delivery will likely affect primary production and nutrient content or 'food quality'; (Cebrian et al., 2009) of seagrasses and their epiphytes, with flow on effects for consumers, which are not well understood. Further knowledge is needed of the contribution of seagrass to the growth and condition of consumers relative to other basal resources and how this may alter under different land use and climate change scenarios.

\section{SEAGRASS ECOSYSTEM FUNCTION}

19. How do different factors (scaled from gene to landscape) influence the functional processes involved in ecosystem service delivery? Evidence of the ability of Australian seagrass to perform functions delivering ecosystem services is highly context-dependent (species, environment, specific spatial and temporal scales) yet these roles are applied to the seagrass group as a whole. There is a need to better understand how the delivery of ecosystem services is affected by specific factors. This information is becoming increasingly important with growing requirements for the valuation of ecosystem services (Naeem et al., 2015).

\section{How do we incorporate structure to functional relationships across multiple spatial and} organisational scales? Understanding complex ecological function requires a systems approach that can be supported by ecosystem modeling. Despite evidence on the role of microbial assemblages (Robertson et al., 1982) and landscape scale attributes (Bell et al., 2006), research on seagrass ecological functions has primarily focused on the habitat scale. Ecosystem 
modeling will allow the conceptualisation of complex relationships and, when coupled with observations and manipulative experiments, can identify important pathways and improve our understanding of the system as a whole.

\section{What is the influence on the ecosystem functions as an ecosystem becomes less resilient,} and how does this erode ecosystem services? The loss and degradation of seagrass to a point which impacts the resilience of the system is assumed to result in a similar loss of ecosystem function, yet the relationship is unlikely to be linear due to the complexities of the systems (Rist et al., 2014). Mesocosm studies could use engineered 'treatments' of altered levels of ecological function that can be subjected to different pressures to test the effect of altered function on resilience.

\section{How do diagenetic processes and the inorganic carbon cycle influence carbon storage in} seagrass meadows? Our knowledge of carbon cycling varies across different seagrass ecosystems (Hyndes et al., 2014). To fully comprehend and predict sequestration capability we need to better understand the diagenetic processes (chemical and physical changes to sediments) that lead to storage and the role of the inorganic carbon cycle in net carbon storage (Mazarrasa et al., 2015). The application of diagenetic biogeochemical modeling, coupled to particle transport-hydrodynamic models, will improve our understanding of carbon cycling within meadows and the fate of exported seagrass in recipient habitats.

23. What are the sediment budget and coastal erosion implications of seagrass loss, and do hydrodynamic conditions affect the resilience of seagrasses to other pressures? Waves and currents are a defining feature of the coast, yet little attention is directed at understanding how seagrasses are affected by and, in turn, affect water movement and processes associated with it (see recommendations in Koch et al., 2009). Addressing these questions requires collaboration between coastal engineers, mathematical modellers and ecologists.

\section{THREATS TO SEAGRASS ECOSYSTEMS}

24. How do seagrasses respond to multiple threats and stressors? Seagrasses live in coastal environments where they are exposed to multiple threats and stressors (Jackson et al., 2001), and in marine systems the interactive effects of stressors are generally more severe than the cumulative effects (Crain et al., 2008). However, most of our predictions of response to threats are based on responses to single stressors (e.g., Ralph et al., 2007). We need to improve our understanding of how multiple threats interact in effecting seagrass response, including threats associated with climate change (e.g., Short and Neckles, 1999). This information can help to prioritize management actions for particular threats or combination of threats and provide insight into the capacity for acclimation to a changing environment.

\section{What are the threats and implications from changes in the ecosystem for seagrass}

habitat? Threats to seagrasses may arise due to changes in other components of the ecosystem; For example, range shifts (Mazaris et al., 2013), species introductions (Williams, 2007), or species loss (de Fouw et al., 2016; Jackson et al., 2001) and changes in the behaviour of resident species can threaten seagrass habitat through changes in interactions such as through increased 
grazing rates (Verges et al., 2014). We need to improve our understanding of interactions in seagrass ecosystems.

\section{What are the mechanisms and thresholds for sub lethal and lethal effects, and the} spatial and temporal scales over which they occur? Seagrass resilience is driven by the ability to resist pressures and recover from impacts (Kilminster et al., 2015). Our ability to predict vulnerability to threats is limited by our understanding of these factors (thresholds) and their mechanisms.

\section{What is the significance of historical changes in stressors to seagrasses over geological} timescales, the most recent Anthropocene, and with projected climate change? Seagrasses evolved $~ 100$ mya and have survived over a range of environmental conditions (Orth et al., 2006). Since the 1950's significant global declines have occurred due to human activities (Waycott et al., 2009) and some aspects of climate change are predicted to threaten seagrasses into the future. Understanding the scale of historical, current, and future pressures can give insight into the evolutionary capacity of seagrasses to adapt to change.

\section{MAPPING AND MONITORING}

\section{How can we standardise methods used to map and monitor seagrass communities in} Australia? Seagrass mapping and monitoring methods are diverse, ranging from broad scale (e.g. remote sensing from satellites) to fine scale (e.g. assessments of shoot counts). Approaches depend on the objectives of the program and resource availability. With at least 54 monitoring programmes in Australia (Kilminster et al., 2015), there is a need to standardise the seagrass metrics (distribution, biomass, seed banks, etc.) measured, and the mapping and monitoring approaches. Could classifications such as species life history, meadow form and habitat type (Kilminster et al., 2015) be a starting point to a national set of mapping and monitoring guidelines?

\section{Should monitoring environmental conditions (abiotic and biotic) be a component of} seagrass monitoring programs? Threats to seagrasses and the services they provide are well documented (Brown et al., 2014; Grech et al., 2012; Grech et al., 2011). These threats potentially reduce the resistance and recovery of seagrasses, and their resilience from pressures associated with climate change. Mapping and monitoring seagrass change and performance is a key priority in many coastal monitoring programs, but understanding the environmental factors that underpin the causes of change are also critical. There should be more emphasis on monitoring a suite of abiotic and biotic environmental conditions.

\section{Which bio-indicators give early warning signs of loss and should they be incorporated} into monitoring programs? A suite of 'early warning' bio-indicators at appropriate temporal and spatial scales should be incorporated into monitoring programs via a pre-determined set of criteria or thresholds, which if exceeded are capable of triggering a management response. Monitoring seagrass health/performance (e.g., carbohydrate stores, metabolomics, C: N: P ratios, level of metals) have the potential to provide early warning signs of seagrass stress. Although there is still much work to be done on identifying robust bio-indicators (McMahon et al., 2013), an initial suite of indicators could be trialled amongst existing monitoring programs for effectiveness and reliability. 


\section{Is optical remote sensing an effective tool in seagrass mapping and monitoring?} Interdisciplinary work between remote sensing and seagrass ecological research is now being coordinated. Remote sensing has successfully been used in clear relatively shallow water where seagrasses can be differentiated from each other or from other substrate types to determine seagrass presence/absence, seagrass metrics (species composition, horizontal projected percentage cover, biomass), maps of shallow meadow boundaries, and to provide information over large spatial (100s $\mathrm{km}^{2}$ ) and temporal (seasons - years) scales (Roelfsema et al., 2013; Roelfsema et al., 2014). Water quality information derived from remote sensing has also been successful in interpreting ecological changes in seagrass (Petus et al., 2014). Further research is required to understand the theoretical and methodological aspects of remote sensing as a tool for mapping and monitoring seagrass, and to integrate optical remote sensing techniques with field based mapping and monitoring techniques.

\section{SEAGRASS MANAGEMENT}

32. Is there a need for a national approach to seagrass management in Australia? Seagrass meadows extend around the Australian continent occurring in all states and territories; however there is no nationwide approach to seagrass management (Butler and Jernakoff, 1999; Coles and Fortes, 2001). The piecemeal and inconsistent approach to management extends to data collection, making any scientific evaluation of protection approaches, the number of permits issued, level of compliance, success of protected area approaches etc. almost impossible (Sheaves et al., 2016). Marine sanctuary zones in Australia poorly represent the extent and variability of seagrass habitat. We cannot be sure at the moment if any of Australia's approaches to seagrass protection are actually effective.

\section{Are there some "must protect" seagrass meadows that we can identify? There is a role} for seagrass scientists to identify some key strategic meadows for special protection. This could include meadows that support populations of iconic protected species such as green sea turtles (Chelonia mydas) or dugong (Dugong dugon); provide ecosystem services such as removing nutrients from eutrophic systems or supporting fisheries populations. There is also a need for the establishment of national seagrass reference sites in areas of low human impact. Meadows could be prioritized for protection based on the relative ecological importance.

\section{In other jurisdictions such as fisheries there are clearly defined links between changes} in target populations and management instruments - can similar tools be applied for seagrass management? If a fish population declines there is a well-established set of tools available to fisheries managers, such as establishing quotas and spatial closures. Could a similar management framework be developed to protect seagrass assets? Models are available which link catchment/watershed management and farm management to water quality and sediment runoff. Good quality catchment models with strong links between model outcomes and land management could empower natural resource managers to make decisions resulting in better outcomes for seagrass.

\section{Would a more rigorous economic analysis of seagrass ecosystem values support} stronger seagrass management and protection? General figures are available (see Costanza et al., 2014) but site-specific economic evaluations of seagrass ecosystem services are few. Detailed economic studies and economic modeling of the costs of damage to seagrass meadows at the estuary scale, such as used in the United States (National Marine Sanctuaries Act 2000, 
467 National Oceanic and Atmospheric Administration, 2013), would provide a useful tool to

468 support better seagrass asset protection and quantify the costs of restoration in the event of 469 their loss.

$470 \quad 36$. How can scientists best communicate with policy makers and managers? Seagrass scientists must find innovative and concise ways to communicate their science to environmental decision makers who are often overloaded with information from competing stakeholders. Report card and "traffic light" summaries are an increasingly popular means to provide a concise visual summary of often complex environmental information and this may be an applicable technique for communicating seagrass status on a national scale. A national approach to reporting ecosystem condition will require the development of standardized and comparable indicators.

\section{SEAGRASS RESTORATION AND REHABILITATION}

479 37. Can we effectively integrate environmental variation with multiple scales of biological organization (genes to metapopulations) to improve and better predict restoration success? Local environments influence seagrass gene expression, seed germination, growth rate, and reproductive output, as well as meadow structure, connectivity, extinction, and recolonization (Dattolo et al., 2013; Kilminster et al., 2015). Understanding these interactions within the context of the species targeted for restoration is critical for developing guiding principles regarding site selection, timing, methodology, and defining success. scales (i.e., metres) to larger scales (i.e., hundreds of metres or more)? Persistent restored meadows are becoming more common in small-scale experimental trials (Tanner et al., 2014), but this success appears difficult to translate to larger scales that meaningfully address seagrass loss. Do the factors limiting seagrass establishment through restoration fundamentally change from small to large scales, or does large scale restoration just require greater effort and resources (Irving et al., 2011)?

39. Is the restoration of seagrass functions implicit in physical restoration, or is additional intervention required? Many questions remain concerning the functionality, and by extension, 'success' of restored seagrass meadows. Data describing seagrass physiology (e.g. photosynthetic rates), population dynamics (e.g. meadow expansion, reproductive output), and ecosystem functions (e.g. carbon capture, nutrient cycling, sediment stabilization, habitat, and food for fauna) would demonstrate contributions of restored seagrass to local ecosystems, and aid the development of indicator-based assessments of success for restoration projects.

40. How do we build resilience in restored seagrass meadows? Traits such as meadow age, size, connectivity, genetic diversity, and inhabiting fauna may help build and maintain resilience (Olds et al., 2012), but data are lacking. Perhaps, where shifting environmental or climate conditions prevent like for like replacement, restoring a species that is naturally more resilient than what has been lost, even if that species wasn't originally present, is more effective longterm (i.e. building novel ecosystems with species more tolerant of disturbance). Crucially, the factors that allow us to 'future-proof' restored seagrasses warrant substantial consideration to ensure contemporary restoration efforts aren't eroded under future conditions. 
509 Seagrass research in Australia and globally has progressed markedly since the last systematic

510 review and research and development plan (Butler and Jernakoff, 1999). The fact that over 70\%

511 of seagrass peer reviewed literature has been generated since the previous review serves to

512 emphasize how quickly the methods and application of seagrass science have advanced. Four

513 general trends have been observed in seagrass research since the turn of the century. Firstly,

514 progression from studies of individual plants or meadows, to studies that incorporate linkages

515 and connections between meadows on regional scales (e.g., Ruiz-Montoya et al., 2015) and

516 among other habitats within the seascape including saltmarsh, mangroves and coral reefs (e.g.,

517 Nagelkerken et al., 2015). Secondly, increased importance of the below-ground biosphere to

518 seagrass resilience is becoming more apparent (Suykerbuyk et al., 2015) including the

519 interaction between seagrass roots and rhizomes, microbial communities and sediment

520 chemistry (e.g., Brodersen et al., 2014; Trevathan-Tackett et al., 2014). Increased focus on

521 knowledge gaps in this area is expected in the future. Thirdly, the study of the interactive effects

522 of multiple stressors on plant function is replacing studies of individual environmental variables

523 (e.g., Collier et al., 2011; York et al., 2013). This is increasingly important with the realization of

524 the complexity of problems like climate change. Finally, from a management perspective there

525 has been a shift from a paradigm of assessment, monitoring and explanation, to one of

526 investigation and understanding involving experimental manipulation, with more emphasis on

527 ecological values and the outcomes of management intervention (Coles et al., 2015; Kilminster

528 et al., 2015).

529 Entire concepts and research fields have also developed since the previous review, particularly

530 around the issues of global climate change. The concept of 'Blue Carbon' has seen considerable

531 research effort focus on quantifying the carbon stocks in Australian seagrasses and valuing their

532 ecosystem service (Lavery et al., 2013). Understanding how seagrasses react to changing ocean

533 temperatures, acidification and sea level rise are also new aspects to global change research

534 that have emerged in the last decade.

535 This evolution in seagrass research builds on earlier studies, and is driven by rapid advances in

536 technology and conceptual approaches which are sure to continue. Modern techniques of

537 remote sensing using satellite imagery, unmanned underwater vehicles and drones equipped

538 with sophisticated camera technology and global positioning systems, and satellite tagging and

539 acoustic telemetry for tracking animals, are transforming the rapid assessment, mapping and

540 monitoring fields. Developments in microelectrodes and optical sensors, microscopy, flow

541 cytometry and stable isotope tracers have advanced understanding in plant physiology,

542 biogeochemistry and trophodynamics (e.g., Brodersen et al., 2015b; Connolly and Waltham,

543 2015; Koren et al., 2015; Trevathan-Tackett et al., 2014). Advances in molecular techniques are

544 improving our understanding of seagrasses from the molecular level through transcriptomic,

545 proteomic, genomic and metabolomic analyses, (e.g., Mazzuca et al., 2013) to the population

546 level with next generation DNA sequencing techniques such as microsatellite markers and

547 single-nucleotide polymorphisms (SNPs) improving our ability to measure genetic diversity,

548 connectivity, resilience, and plant adaptation (e.g., Oetjen et al., 2010). Genetic sequencing is

549 also being used to characterize microbial communities associated with seagrasses (Sun et al.,

5502015 ) and advances in environmental sampling (eDNA) are making this possible in larger

551 faunal communities through metabarcoding techniques (Cowart et al., 2015). Increases in

552 computing power has allowed for advances in statistical and spatial analyses and modeling, and

553 have led to the new field of bioinformatics that enables the exploration of very large datasets 
554 produced by new technologies (Lucas et al., 2012; Procaccini et al., 2007). The synthesis of the

555 large volumes of environmental and experimental data into models of habitat suitability, threat

556 assessments, growth dynamics in relation to environment and climate, trophodynamics, and

557 hydrodynamics will lead to greater predictive power of how seagrasses will respond to future

558 scenarios of change and perturbation (e.g., Grech and Coles, 2010; Maxwell et al., 2015; Petus et

559 al., 2014; Saunders et al., 2013; York et al., 2012). Understanding the complexities of the

560 interactions affecting seagrass ecosystem and the growing human pressures that are impacting

561 them will also require an interdisciplinary approach to investigation bringing together

562 researchers from many different fields.

563 Gaps remain however, as our present review has emphasized. We do not have a national

564 approach to seagrass management and research, with federal, state, territory and local

565 jurisdictions having differing rules, approaches, and emphases. Large gaps remain in our

566 knowledge of even the extent of seagrass meadows along the northern Australian coastline and

567 in deeper $(>15 \mathrm{~m})$ waters. Taxonomic and systematic progress has been slow, and controversy

568 over species classifications still exists despite improved molecular techniques for determining

569 phylogeny. The lack of new seagrass researchers trained in recognising the taxonomic features

570 of seagrass families that compliment new molecular toolkits has restricted progress in these

571 areas. Without a clear picture of species and their history other research approaches are

572 compromised.

573 Restoration of seagrass in Australia has gained renewed attention and is a fast growing area for

574 research; however the questions proposed in this review start with basic knowledge of scale

575 and reproductive output, seedling germination and success. To date, most efforts in Australia

576 have been small-scale and have had a high degree of failure; successful and cost-effective

577 restoration at larger spatial scales seems a long way off (van Katwijk et al., 2015). A greater

578 understanding of restoration success will come from a synthesis of the growing knowledge base

579 from other areas of research including reproduction and seed ecology, sediment chemistry and

580 microbial activity, genetic diversity, natural resilience, connectivity, and the use of the latest

581 technologies (Williams et al., 2014).

582 The Australian research community has advanced our knowledge of seagrass ecosystems

583 enormously over the previous four decades. This review has identified gaps in our

584 understanding of seagrass systems based on Australian experience that is relevant to the

585 broader global research community. We cover a wide range of research fields and incorporate a

586 divergence of views as to what are the top priorities but common themes, synergies, and

587 overlaps can be seen in the priorities outlined by various groups. While it is not possible to

588 predict all future discoveries related to seagrass ecology as evidenced from the previous review

589 (Butler and Jernakoff, 1999), we provide a platform for a more coordinated approach. The

590 challenge now is to build on our current knowledge - to understand the complex interactions

591 between seagrasses and their environment, to provide advice for best management practice,

592 and to protect the important habitats and the ecological systems dependent on them. 
594 Aragones, L., Lawler, I., Foley, W., Marsh, H., 2006. Dugong grazing and turtle cropping: grazing optimization in tropical seagrass systems? Oecologia 149, 635-647.

Atwood, T.B., Connolly, R.M., Ritchie, E.G., Lovelock, C.E., Heithaus, M.R., Hays, G.C., Fourqurean, J.W., Macreadie, P.I., 2015. Predators help protect carbon stocks in blue carbon ecosystems.

598 Nature Climate Change 5, 1038-1045.

599 Backman, T.W.H., 1991. Genotypic and phenotypic variability of Zostera marina on the west 600 coast of north America. Canadian Journal of Botany 69, 1361-1371.

601 Barbier, E.B., Hacker, S.D., Kennedy, C., Koch, E.W., Stier, A.C., Silliman, B.R., 2011. The value of estuarine and coastal ecosystem services. Ecological Monographs 81, 169-193.

603

604

605

606

607

608

609

610

611

612

613

614

615

616

617

618

619

620

621

622

623

624

625

626

627

628

629

630

631

Bell, S.S., Fonseca, M.S., Stafford, N.B., 2006. Seagrass ecology: new contributions from a landscape perspective, in: Larkum, A.W.D., Orth, R.J., Duarte, C.M. (Eds.), Seagrasses: Biology, Ecology and Conservation. Springer, Amsterdam, pp. 625-645.

Brodersen, K.E., Lichtenberg, M., Paz, L.-C., Kühl, M., 2015a. Epiphyte-cover on seagrass (Zostera marina L.) leaves impedes plant performance and radial $\mathrm{O}_{2}$ loss from the below-ground tissue. Frontiers in Marine Science 2, 58.

Brodersen, K.E., Nielsen, D.A., Ralph, P.J., Kühl, M., 2014. A split flow chamber with artificial sediment to examine the below-ground microenvironment of aquatic macrophytes. Marine Biology 161, 2921-2930.

Brodersen, K.E., Nielsen, D.A., Ralph, P.J., Kühl, M., 2015b. Oxic microshield and local pH enhancement protects Zostera muelleri from sediment derived hydrogen sulphide. New Phytologist 205, 1264-1276.

Brown, C.J., Saunders, M.I., Possingham, H.P., Richardson, A.J., 2014. Interactions between global and local stressors of ecosystems determine management effectiveness in cumulative impact mapping. Diversity and Distributions 20, 538-546.

Butler, A.J., Jernakoff, P., 1999. Seagrass in Australia: strategic review and development of an R \& D plan. CSIRO Publishing Collingwood,, Australia.

Callmander, M.W., Schatz, G.E., Lowry, P.P., 2005. IUCN Red List assessment and the Global Strategy for Plant Conservation: taxonomists must act now. Taxon 54, 1047-1050.

Casal, J.J., 2013. Photoreceptor Signaling Networks in Plant Responses to Shade, in: Merchant, S.S. (Ed.), Annual Review of Plant Biology, Vol 64, pp. 403-427.

Cebrian, J., Shurin, J.B., Borer, E.T., Cardinale, B.J., Ngai, J.T., Smith, M.D., Fagan, W.F., 2009. Producer Nutritional Quality Controls Ecosystem Trophic Structure. Plos One 4, e4929.

Coles, R.G., Fortes, M., 2001. Protecting seagrass—approaches and methods, in: Short, F.T., Coles, R.G. (Eds.), Global seagrass research methods. Amsterdam: Elsevier. Elsevier, Amsterdam, pp. 445-463.

Coles, R.G., Rasheed, M.A., McKenzie, L., Grech, A., York, P.H., Sheaves, M., McKenna, S., Bryant, C., 2015. The Great Barrier reef World Heritage Area seagrasses: Managing this iconic Australian ecosystem resource for the future. Estuarine, Coastal and Shelf Science 153, A1-A12. 
Coles, R.G., Short, F.T., Fortes, M.D., Kuo, J., 2014. Twenty years of seagrass networking and advancing seagrass science: The International Seagrass Biology Workshop Series. Pacific Conservation Biology 20, 8-16.

Collier, C.J., Uthicke, S., Waycott, M., 2011. Thermal tolerance of two seagrass species at contrasting light levels: Implications for future distribution in the Great Barrier Reef. Limnology and Oceanography 56, 2200-2210.

Connolly, R.M., Waltham, N.J., 2015. Spatial analysis of carbon isotopes reveals seagrass contribution to fishery food web. Ecosphere 6, 148.

Cook, K., Vanderklift, M.A., Poore, A.G.B., 2011. Strong effects of herbivorous amphipods on epiphyte biomass in a temperate seagrass meadow. Marine Ecology Progress Series 442, 263269.

Costanza, R., de Groot, R., Sutton, P., van der Ploeg, S., Anderson, S.J., Kubiszewski, I., Farber, S., Turner, R.K., 2014. Changes in the global value of ecosystem services. Global Environmental Change 26, 152-158.

Cowart, D.A., Pinheiro, M., Mouchel, O., Maguer, M., Grall, J., Miné, J., Arnaud-Haond, S., 2015. Metabarcoding Is Powerful yet Still Blind: A Comparative Analysis of Morphological and Molecular Surveys of Seagrass Communities. PloS One 10, e0117562.

Coyer, J.A., Hoarau, G., Kuo, J., Tronholm, A., Veldsink, J., Olsen, J.L., 2013. Phylogeny and temporal divergence of the seagrass family Zosteraceae using one nuclear and three chloroplast loci. Systematics and Biodiversity 11, 271-284.

Crain, C.M., Kroeker, K., Halpern, B.S., 2008. Interactive and cumulative effects of multiple human stressors in marine systems. Ecology Letters 11, 1304-1315.

Crump, B.C., Koch, E.W., 2008. Attached bacterial populations shared by four species of aquatic angiosperms. Applied and Environmental Microbiology 74, 5948-5957.

Dattolo, E., Gu, J., Bayer, P.E., Mazzuca, S., Serra, I.A., Spadafora, A., Bernardo, L., Natali, L., Cavallini, A., Procaccini, G., 2013. Acclimation to different depths by the marine angiosperm Posidonia oceanica: transcriptomic and proteomic profiles. Frontiers in Plant Science 4, 195.

Davis, J.P., Pitt, K.A., Fry, B., Olds, A.D., Connolly, R.M., 2014. Seascape-scale trophic links for fish on inshore coral reefs. Coral Reefs 33, 897-907.

de Fouw, J., Govers, L.L., van de Koppel, J., van Belzen, J., Dorigo, W., Cheikh, M.A.S., Christianen, M.J., van der Reijden, K.J., van der Geest, M., Piersma, T., 2016. Drought, Mutualism Breakdown, and Landscape-Scale Degradation of Seagrass Beds. Current Biology.

den Hartog, C., 1970. The Seagrasses of the World. North-Holland Publishing Co., Amsterdam.

Di Maida, G., Tomasello, A., Sciandra, M., Pirrotta, M., Milazzo, M., Calvo, S., 2013. Effect of different substrata on rhizome growth, leaf biometry and shoot density of Posidonia oceanica. Marine Environmental Research 87-88, 96-102.

Duarte, C.M., 1999. Seagrass ecology at the turn of the millennium: challenges for the new century. Aquatic Botany 65, 7-20. 
670

671

672

673

674

675

676

677

678

679

680

681

682

683

684

685

686

687

688

689

690

691

692

693

694

695

696

697

698

699

700

701

702

703

704

705

706

707

708

709

710

Ebrahim, A., Olds, A.D., Maxwell, P.S., Pitt, K.A., Burfeind, D.D., Connolly, R.M., 2014. Herbivory in a subtropical seagrass ecosystem: separating the functional role of different grazers. Marine Ecology Progress Series.

Ghorai, D., Sen, H.S., 2015. Role of climate change in increasing occurrences oceanic hazards as a potential threat to coastal ecology. Natural Hazards 75, 1223-1245.

Gillanders, B.M., Elsdon, T.S., Halliday, I.A., Jenkins, G.P., Robins, J.B., Valesini, F.J., 2011. Potential effects of climate change on Australian estuaries and fish utilising estuaries: a review. Marine and Freshwater Research 62, 1115-1131.

Golicz, A.A., Schliep, M., Lee, H.T., Larkum, A.W.D., Dolferus, R., Batley, J., Chan, C.-K.K., Sablok, G., Ralph, P.J., Edwards, D., 2015. Genome-wide survey of the seagrass Zostera muelleri suggests modification of the ethylene signalling network. Journal of Experimental Botany 66, 1489-1498.

Grech, A., Chartrand-Miller, K., Erftemeijer, P., Fonseca, M., McKenzie, L., Rasheed, M., Taylor, H., Coles, R., 2012. A comparison of threats, vulnerabilities and management approaches in global seagrass bioregions. Environmental Research Letters 7, 024006.

Grech, A., Coles, R., Marsh, H., 2011. A broad-scale assessment of the risk to coastal seagrasses from cumulative threats. Marine Policy 35, 560-567.

Grech, A., Coles, R.G., 2010. An ecosystem-scale predictive model of coastal seagrass distribution. Aquatic Conservation: Marine and Freshwater Ecosystems 20, 437-444.

Green, E.P., Short, F.T., 2003. World Atlas of Seagrass. University of California Press, Berkley and Los Angeles.

Hansen, J.W., Udy, J.W., Perry, C.J., Dennison, W.C., Lomstein, B.A., 2000. Effect of the seagrass Zostera capricorni on sediment microbial processes. Marine Ecology Progress Series 199, 83-96.

Hays, G.C., Ferreira, L.C., Sequeira, A.M.M., Meekan, M.G., Duarte, C.M., Bailey, H., Bailleul, F., Bowen, W.D., Caley, M.J., Costa, D.P., Eguíluz, V.M., Fossette, S., Friedlaender, A.S., Gales, N., Gleiss, A.C., Gunn, J., Harcourt, R., Hazen, E.L., Heithaus, M.R., Heupel, M., Holland, K., Horning, M., Jonsen, I., Kooyman, G.L., Lowe, C.G., Madsen, P.T., Marsh, H., Phillips, R.A., Righton, D., RopertCoudert, Y., Sato, K., Shaffer, S.A., Simpfendorfer, C.A., Sims, D.W., Skomal, G., Takahashi, A., Trathan, P.N., Wikelski, M., Womble, J.N., Thums, M., 2016. Key Questions in Marine Megafauna Movement Ecology. Trends in Ecology \& Evolution 31, 463-475.

Heithaus, M.R., Wirsing, A.J., Burkholder, D., Thomson, J., Dill, L.M., 2009. Towards a predictive framework for predator risk effects: the interaction of landscape features and prey escape tactics. Journal of Animal Ecology 78, 556-562.

Hemminga, M., Duarte, C.M., 2000. Seagrass Ecology. Cambridge University Press.

Hemminga, M.A., 1998. The root/rhizome system of seagrasses: An asset and a burden. Journal of Sea Research 39, 183-196.

Huijbers, C.M., Connolly, R.M., Pitt, K.A., Schoeman, D.S., Schlacher, T.A., Burfeind, D.D., Steele, C., Olds, A.D., Maxwell, P.S., Babcock, R.C., Rissik, D., 2015. Conservation benefits of marine reserves are undiminished near coastal rivers and cities. Conservation Letters 8, 312-319.

Hyndes, G.A., Nagelkerken, I., McLeod, R.J., Connolly, R.M., Lavery, P.S., Vanderklift, M.A., 2014. Mechanisms and ecological role of carbon transfer within coastal seascapes. Biological Reviews $89,232-254$. 
Irving, A.D., Connell, S.D., Russell, B.D., 2011. Restoring Coastal Plants to Improve Global Carbon Storage: Reaping What We Sow. Plos One 6, e18311.

Irving, A.D., Tanner, J.E., Seddon, S., Miller, D., Collings, G.J., Wear, R.J., Hoare, S.L., Theil, M.J., 2010. Testing alternate ecological approaches to seagrass rehabilitation: links to life-history traits. Journal of Applied Ecology 47, 1119-1127.

Jackson, J.B.C., Kirby, M.X., Berger, W.H., Bjorndal, K.A., Botsford, L.W., Bourque, B.J., Bradbury, R.H., Cooke, R., Erlandson, J., Estes, J.A., Hughes, T.P., Kidwell, S., Lange, C.B., Lenihan, H.S., Pandolfi, J.M., Peterson, C.H., Steneck, R.S., Tegner, M.J., Warner, R.R., 2001. Historical overfishing and the recent collapse of coastal ecosystems. Science 293, 629-638.

Jacobs, S.W.L., Les, D.H., 2009. New combinations in Zostera (Zosteraceae). Telopea 12, 419-423.

Jones, T.C., Gemmill, C.E.C., Pilditch, C.A., 2008. Genetic variability of New Zealand seagrass (Zostera muelleri) assessed at multiple spatial scales. Aquatic Botany 88, 39-46.

Kendrick, G.A., Waycott, M., Carruthers, T.J.B., Cambridge, M.L., Hovey, R., Krauss, S.L., Lavery, P.S., Les, D.H., Lowe, R.J., Mascaro I Vidal, O., Ooi, J.L.S., Orth, R.J., Rivers, D.O., Ruiz-Montoya, L., Sinclair, E.A., Statton, J., van Dijk, J.K., Verduin, J.J., 2012. The Central Role of Dispersal in the Maintenance and Persistence of Seagrass Populations. Bioscience 62, 56-65.

Kilminster, K., McMahon, K., Waycott, M., Kendrick, G.A., Scanes, P., McKenzie, L., O'Brien, K.R., Lyons, M., Ferguson, A., Maxwell, P., 2015. Unravelling complexity in seagrass systems for management: Australia as a microcosm. Science of The Total Environment 534, 97-109.

Kim, K.C., Byrne, L.B., 2006. Biodiversity loss and the taxonomic bottleneck: emerging biodiversity science. Ecological Research 21, 794-810.

Koch, E.W., Barbier, E.B., Silliman, B.R., Reed, D.J., Perillo, G.M.E., Hacker, S.D., Granek, E.F., Primavera, J.H., Muthiga, N., Polasky, S., Halpern, B.S., Kennedy, C.J., Kappel, C.V., Wolanski, E., 2009. Non-linearity in ecosystem services: Temporal and spatial variability in coastal protection. Frontiers in Ecology and the Environment 7, 29-37.

Koren, K., Brodersen, K.E., Jakobsen, S.L., Kühl, M., 2015. Optical Sensor Nanoparticles in Artificial Sediments-A New Tool To Visualize 02 Dynamics around the Rhizome and Roots of Seagrasses. Environmental Science \& Technology 49, 2286-2292.

Kuo, J., 2005. A revision of the genus Heterozostera (Zosteraceae). Aquatic Botany 81, 97-140.

Kuo, J., Den Hartog, C., 2001. Seagrass taxonomy and identification key, in: Short, F.T., Coles, R.G. (Eds.), Global Seagrass Research Methods. Elsevier Science, Amsterdam, pp. 31-58.

Larkum, A.W.D., 1977. Recent research on seagrass communities in Australia, in: McRoy, C.P., Helfferich, C. (Eds.), Seagrass Ecosystems: A Scientific Perspective. Marcel Dekker Inc., New York, pp. 247-262.

Larkum, A.W.D., McComb, A.J., Shepherd, S.A., 1989. Biology of Seagrasses: A Tretise on the Biology of Seagrass with Special Reference to the Australian Region. Elsevier, Amsterdam.

Larkum, A.W.D., Orth, R.J., Duarte, C.M., 2006. Seagrasses: Biology, Ecology and Conservation. Springer. 
Lavery, P.S., Mateo, M.A., Serrano, O., Rozaimi, M., 2013. Variability in the carbon storage of seagrass habitats and its implications for global estimates of blue carbon ecosystem service. Plos One 8, e73748.

Lee, K.S., Park, S.R., Kim, Y.K., 2007. Effects of irradiance, temperature, and nutrients on growth dynamics of seagrasses: A review. Journal of Experimental Marine Biology and Ecology 350, 144-175.

755

756

757

758

759

760

761

762

763

764

765

766

767

768

769

770

Lucas, C., Thangaradjou, T., Papenbrock, J., 2012. Development of a DNA Barcoding System for Seagrasses: Successful but Not Simple. PLoS ONE 7, e29987.

Macreadie, P.I., Trevathan-Tackett, S.M., Skilbeck, C.G., Sanderman, J., Curlevski, N., Jacobsen, G., Seymour, J.R., 2015. Losses and recovery of organic carbon from a seagrass ecosystem following disturbance. Proc. R. Soc. B 282, 20151537.

Macreadie, P.I., York, P.H., Sherman, C.D.H., 2014. Resilience of Zostera muelleri seagrass to small-scale disturbances: the relative importance of asexual versus sexual recovery. Ecology and Evolution 4, 450-461.

Maxwell, P.S., Pitt, K.A., Burfeind, D.D., Olds, A.D., Babcock, R.C., Connolly, R.M., 2014. Phenotypic plasticity promotes persistence following severe events: physiological and morphological responses of seagrass to flooding. Journal of Ecology 102, 54-64.

Maxwell, P.S., Pitt, K.A., Olds, A.D., Rissik, D., Connolly, R.M., 2015. Identifying habitats at risk: simple models can reveal complex ecosystem dynamics. Ecological Applications 25, 573-587.

Mazaris, A.D., Kallimanis, A.S., Pantis, J.D., Hays, G.C., 2013. Phenological response of sea turtles to environmental variation across a species' northern range. Proceedings of the Royal Society BBiological Sciences 280, 20122397.

Mazarrasa, I., Marbà, N., Lovelock, C.E., Serrano, O., Lavery, P.S., Fourqurean, J.W., Kennedy, H., Mateo, M.A., Krause-Jensen, D., Steven, A.D.L., Duarte, C.M., 2015. Seagrass meadows as a globally significant carbonate reservoir. Biogeosciences 12, 4993-5003.

Mazzuca, S., Björk, M., Beer, S., Felisberto, P., Gobert, S., Procaccini, G., Runcie, J., Silva, J., Borges, A.V., Brunet, C., 2013. Establishing research strategies, methodologies and technologies to link genomics and proteomics to seagrass productivity, community metabolism, and ecosystem carbon fluxes. Frontiers in Plant Science 4, 38.

McKenna, S., Jarvis, J., Sankey, T., Reason, C., Coles, R., Rasheed, M., 2015. Declines of seagrasses in a tropical harbour, North Queensland, Australia, are not the result of a single event. Journal of Biosciences 40, 389-398.

McMahon, K., Collier, C., Lavery, P.S., 2013. Identifying robust bioindicators of light stress in seagrasses: A meta-analysis. Ecological Indicators 30, 7-15.

McMahon, K., van Dijk, K.-J., Ruiz-Montoya, L., Kendrick, G.A., Krauss, S.L., Waycott, M., Verduin, J., Lowe, R., Statton, J., Brown, E., Duarte, C., 2014. The movement ecology of seagrasses. Proceedings of the Royal Society B: Biological Sciences 281, 20140878.

McNeil, P., 2015. National Species List, Australian Plant Index Documentation. Accessed 12 July 2015. <https://biodiversity.org.au/nsl/docs/main.html>. 
Moriarty, D.J.W., Boon, P.I., Hansen, J.A., Hunt, W.G., Poiner, I.R., Pollard, P.C., Skyring, G.W., White, D.C., 1985. Microbial biomass and productivity in seagrass beds. Geomicrobiology 790 Journal 4, 21-51.

Naeem, S., Ingram, J.C., Varga, A., Agardy, T., Barten, P., Bennett, G., Bloomgarden, E., Bremer, L.L., Burkill, P., Cattau, M., Ching, C., Colby, M., Cook, D.C., Costanza, R., DeClerck, F., Freund, C., Gartner, T., Benner, R.G., Gunderson, J., Jarrett, D., Kinzig, A.P., Kiss, A., Koontz, A., Kumar, P., Lasky, J.R., Masozera, M., Meyers, D., Milano, F., Naughton-Treves, L., Nichols, E., Olander, L., Olmsted, P., Perge, E., Perrings, C., Polasky, S., Potent, J., Prager, C., Quetier, F., Redford, K., Saterson, K., Thoumi, G., Vargas, M.T., Vickerman, S., Weisser, W., Wilkie, D., Wunder, S., 2015. Get the science right when paying for nature's services. Science 347, 1206-1207.

Nagelkerken, I., Sheaves, M., Baker, R., Connolly, R.M., 2015. The seascape nursery: a novel spatial approach to identify and manage nurseries for coastal marine fauna. Fish and Fisheries $16,362-371$.

Oetjen, K., Ferber, S., Dankert, I., Reusch, T.H., 2010. New evidence for habitat-specific selection in Wadden Sea Zostera marina populations revealed by genome scanning using SNP and microsatellite markers. Marine Biology 157, 81-89.

Olds, A.D., Pitt, K.A., Maxwell, P.S., Connolly, R.M., 2012. Synergistic effects of reserves and connectivity on ecological resilience. Journal of Applied Ecology 49, 1195-1203.

Orth, R.J., Carruthers, T.J., Dennison, W.C., Duarte, C.M., Fourqurean, J.W., Heck Jr, K.L., Hughes, A.R., Kendrick, G.A., Kenworthy, W.J., Olyarnik, S., 2006. A global crisis for seagrass ecosystems. Bioscience 56, 987-996.

Orth, R.J., Harwell, M.C., Bailey, E.M., Bartholomew, A., Jawad, J.T., Lombana, A.V., Moore, K.A., Rhode, J.M., Woods, H.E., 2000. A review of issues in seagrass seed dormancy and germination: implications for conservation and restoration. Marine Ecology Progress Series 200, 277-288.

Panno, L., Bruno, M., Voyron, S., Anastasi, A., Gnavi, G., Miserere, L., Varese, G.C., 2013. Diversity, ecological role and potential biotechnological applications of marine fungi associated to the seagrass Posidonia oceanica. New biotechnology 30, 685-694.

Petus, C., Collier, C., Devlin, M., Rasheed, M., McKenna, S., 2014. Using MODIS data for understanding changes in seagrass meadow health: A case study in the Great Barrier Reef (Australia). Marine Environmental Research 98, 68-85.

Procaccini, G., Olsen, J.L., Reusch, T.B.H., 2007. Contribution of genetics and genomics to seagrass biology and conservation. Journal of Experimental Marine Biology and Ecology 350, 234-259.

Ralph, P.J., Durako, M.J., Enriquez, S., Collier, C.J., Doblin, M.A., 2007. Impact of light limitation on seagrasses. Journal of Experimental Marine Biology and Ecology 350, 176-193.

Rist, L., Felton, A., Nyström, M., Troell, M., Sponseller, R.A., Bengtsson, J., Österblom, H., Lindborg, R., Tidåker, P., Angeler, D.G., Milestad, R., Moen, J., 2014. Applying resilience thinking to production ecosystems. Ecosphere 5, 73.

Robertson, M.L., Mills, A.L., Zieman, J.C., 1982. Microbial synthesis of detritus-like particulates from dissolved organic carbon released by tropical seagrasses. Mar. Ecol. Prog. Ser. 7, 279-285.

Roelfsema, C., Kovacs, E.M., Saunders, M.I., Phinn, S., Lyons, M., Maxwell, P., 2013. Challenges of remote sensing for quantifying changes in large complex seagrass environments. Estuarine Coastal and Shelf Science 133, 161-171. 
Roelfsema, C.M., Lyons, M., Kovacs, E.M., Maxwell, P., Saunders, M.I., Samper-Villarreal, J., Phinn, S.R., 2014. Multi-temporal mapping of seagrass cover, species and biomass: A semi-automated object based image analysis approach. Remote Sensing of Environment 150, 172-187.

Ruiz-Montoya, L., Lowe, R.J., Kendrick, G.A., 2015. Contemporary connectivity is sustained by wind- and current-driven seed dispersal among seagrass meadows. Mov Ecol 3, 1-14.

Saunders, M.I., Leon, J., Phinn, S.R., Callaghan, D.P., O'Brien, K.R., Roelfsema, C.M., Lovelock, C.E., Lyons, M.B., Mumby, P.J., 2013. Coastal retreat and improved water quality mitigate losses of seagrass from sea level rise. Global Change Biology 19, 2569-2583.

Sheaves, M., Coles, R., Dale, P., Grech, A., Pressey, R.L., Waltham, N.J., 2016. Enhancing the Value and Validity of EIA: Serious Science to Protect Australia's Great Barrier Reef. Conservation Letters.

Short, F.T., Carruthers, T., Dennison, W., Waycott, M., 2007. Global seagrass distribution and diversity: A bioregional model. Journal of Experimental Marine Biology and Ecology 350, 3-20.

Short, F.T., Coles, R.G., 2001. Global Seagrass Research Methods. Elsevier Science B. V., Amsterdam.

Short, F.T., Neckles, H.A., 1999. The effects of global climate change on seagrasses. Aquatic Botany 63, 169-196.

Short, F.T., Polidoro, B., Livingstone, S.R., Carpenter, K.E., Bandeira, S., Bujang, J.S., Calumpong, H.P., Carruthers, T.J.B., Coles, R.G., Dennison, W.C., Erftemeijer, P.L.A., Fortes, M.D., Freeman, A.S., Jagtap, T.G., Kamal, A.H.M., Kendrick, G.A., Judson Kenworthy, W., La Nafie, Y.A., Nasution, I.M., Orth, R.J., Prathep, A., Sanciangco, J.C., Tussenbroek, B.v., Vergara, S.G., Waycott, M., Zieman, J.C., 2011. Extinction risk assessment of the world's seagrass species. Biological Conservation 144, 1961-1971.

Sinclair, E.A., Gecan, I., Krauss, S.L., Kendrick, G.A., 2014a. Against the odds: complete outcrossing in a monoecious clonal seagrass Posidonia australis (Posidoniaceae). Annals of Botany 113, 1185-1196.

Sinclair, E.A., Krauss, S.L., Anthony, J., Hovey, R., Kendrick, G.A., 2014b. The interaction of environment and genetic diversity within meadows of the seagrass Posidonia australis (Posidoniaceae). Marine Ecology Progress Series 506, 87-98.

Sinclair, E.A., Statton, J., Hovey, R., Anthony, J.M., Dixon, K.W., Kendrick, G.A., 2016. Reproduction at the extremes: pseudovivipary, hybridization and genetic mosaicism in Posidonia australis (Posidoniaceae). Annals of Botany 117, 237-247.

Smith, T.M., Jenkins, G.R., Hutchinson, N., 2012. Seagrass edge effects on fish assemblages in deep and shallow habitats. Estuarine Coastal and Shelf Science 115, 291-299.

Statton, J., Dixon, K.W., Hovey, R.K., Kendrick, G.A., 2012. A comparative assessment of approaches and outcomes for seagrass revegetation in Shark Bay and Florida Bay. Marine and Freshwater Research 63, 984-993.

Sullivan, B.K., Sherman, T.D., Damare, V.S., Lilje, O., Gleason, F.H., 2013. Potential roles of Labyrinthula spp. in global seagrass population declines. Fungal Ecology 6, 328-338.

Sun, F., Zhang, X., Zhang, Q., Liu, F., Zhang, J., Gong, J., 2015. Seagrass (Zostera marina) colonization promotes the accumulation of diazotrophic bacteria and alters the relative 
871

872

873

874

875

876

877

878

879

880

881

882

883

884

885

886

887

888

889

890

891

892

893

894

895

896

897

898

899

900

901

902

903

904

905

906

907

908

909

910

911

abundances of specific bacterial lineages involved in benthic carbon and sulfur cycling. Applied and Environmental Microbiology 81, 6901-6914.

Sutherland, W.J., Freckleton, R.P., Godfray, H.C.J., Beissinger, S.R., Benton, T., Cameron, D.D., Carmel, Y., Coomes, D.A., Coulson, T., Emmerson, M.C., Hails, R.S., Hays, G.C., Hodgson, D.J., Hutchings, M.J., Johnson, D., Jones, J.P.G., Keeling, M.J., Kokko, H., Kunin, W.E., Lambin, X., Lewis, O.T., Malhi, Y., Mieszkowska, N., Milner-Gulland, E.J., Norris, K., Phillimore, A.B., Purves, D.W., Reid, J.M., Reuman, D.C., Thompson, K., Travis, J.M.J., Turnbull, L.A., Wardle, D.A., Wiegand, T., 2013. Identification of 100 fundamental ecological questions. Journal of Ecology 101, 58-67.

Suykerbuyk, W., Bouma, T.J., Govers, L.L., Giesen, K., de Jong, D.J., Herman, P., Hendriks, J., van Katwijk, M.M., 2015. Surviving in Changing Seascapes: Sediment Dynamics as Bottleneck for Long-Term Seagrass Presence. Ecosystems, 1-15.

Tanner, J.E., Irving, A.D., Fernandes, M., Fotheringham, D., McArdle, A., Murray-Jones, S., 2014. Seagrass rehabilitation off metropolitan Adelaide: a case study of loss, action, failure and success. Ecological Management \& Restoration 15, 168-179.

Thomson, A.C.G., York, P.H., Smith, T.M., Sherman, C.D.H., Booth, D.J., Keough, M.J., Ross, D.J., Macreadie, P.I., 2015. Seagrass Viviparous Propagules as a Potential Long-Distance Dispersal Mechanism. Estuaries and Coasts 38, 927-940.

Touchette, B.W., Burkholder, J.M., 2000. Overview of the physiological ecology of carbon metabolism in seagrasses. Journal of Experimental Marine Biology and Ecology 250, 169-205.

Trevathan-Tackett, S., Macreadie, P., Ralph, P., Seymour, J., 2014. Detachment and flow cytometric quantification of seagrass-associated bacteria. Journal of Microbiological Methods $102,23-25$.

Unsworth, R.K.F., Collier, C.J., Waycott, M., McKenzie, L.J., Cullen-Unsworth, L.C., 2015. A framework for the resilience of seagrass ecosystems. Marine Pollution Bulletin 100, 34-46.

van Katwijk, M.M., Thorhaug, A., Marbà, N., Orth, R.J., Duarte, C.M., Kendrick, G.A., Althuizen, I.H.J., Balestri, E., Bernard, G., Cambridge, M.L., Cunha, A., Durance, C., Giesen, W., Han, Q., Hosokawa, S., Kiswara, W., Komatsu, T., Lardicci, C., Lee, K.-S., Meinesz, A., Nakaoka, M., O'Brien, K.R., Paling, E.I., Pickerell, C., Ransijn, A.M.A., Verduin, J.J., 2015. Global analysis of seagrass restoration: the importance of large-scale planting. Journal of Applied Ecology.

van Keulen, M., Paling, E.I., Walker, C.J., 2003. Effect of planting unit size and sediment stabilization on seagrass transplants in Western Australia. Restoration Ecology 11, 50-55.

Verges, A., Steinberg, P.D., Hay, M.E., Poore, A.G.B., Campbell, A.H., Ballesteros, E., Heck, K.L., Booth, D.J., Coleman, M.A., Feary, D.A., Figueira, W., Langlois, T., Marzinelli, E.M., Mizerek, T., Mumby, P.J., Nakamura, Y., Roughan, M., van Sebille, E., Sen Gupta, A., Smale, D.A., Tomas, F., Wernberg, T., Wilson, S.K., 2014. The tropicalization of temperate marine ecosystems: climatemediated changes in herbivory and community phase shifts. Proceedings of the Royal Society BBiological Sciences 281, 20140846.

Verhoeven, M.P.C., Kelaher, B.P., Bishop, M.J., Ralph, P.J., 2012. Epiphyte grazing enhances productivity of remnant seagrass patches. Austral Ecology 37, 885-892.

Waycott, M., Duarte, C.M., Carruthers, T.J., Orth, R.J., Dennison, W.C., Olyarnik, S., Calladine, A., Fourqurean, J.W., Heck, K.L., Hughes, A.R., 2009. Accelerating loss of seagrasses across the globe 
912 threatens coastal ecosystems. Proceedings of the National Academy of Sciences 106, 12377-

91312381.

914 Waycott, M., Procaccini, G., Les, D.H., Reusch, T.B.H., 2006. Seagrass evolution, ecology and

915 conservation: A genetic perspective, in: Larkum, A.W.D., Orth, R.J., Duarte, C.M. (Eds.),

916 Seagrasses: Biology, Ecology and Conservation. Springer, Dordrecht, pp. 25-50.

917 Williams, A.V., Nevill, P.G., Krauss, S.L., 2014. Next generation restoration genetics: applications

918 and opportunities. Trends in Plant Science 19, 529-537.

919 Williams, S.L., 2007. Introduced species in seagrass ecosystems: Status and concerns. Journal of

920 Experimental Marine Biology and Ecology 350, 89-110.

921 Wilson, S., Adjeroud, M., Bellwood, D., Berumen, M.L., Booth, D., Bozec, Y.-M., Chabanet, P., Cheal, 922 A., Cinner, J., Depczynski, M., 2010. Crucial knowledge gaps in current understanding of climate 923 change impacts on coral reef fishes. The Journal of experimental biology 213, 894-900.

924 York, P.H., Gruber, R.K., Hill, R., Ralph, P.J., Booth, D.J., Macreadie, P.I., 2013. Physiological and 925 Morphological Responses of the Temperate Seagrass Zostera muelleri to Multiple Stressors:

926 Investigating the Interactive Effects of Light and Temperature. PLoS ONE 8, e76377.

927 York, P.H., Kelaher, B.P., Booth, D.J., Bishop, M.J., 2012. Trophic responses to nutrient enrichment 928 in a temperate seagrass food chain. Marine Ecology Progress Series 449, 291-296. 


\section{Accepted Manuscript}

Identifying knowledge gaps in seagrass research and management: An Australian perspective

Paul H. York, Timothy M. Smith, Rob G. Coles, Skye A. McKenna, Rod M. Connolly, Andrew D. Irving, Emma L. Jackson, Kathryn McMahon, John W. Runcie, Craig D.H.

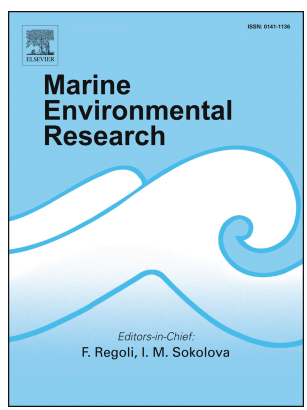
Sherman, Brooke K. Sullivan, Stacy M. Trevathan-Tackett, Kasper E. Brodersen, Alex B. Carter, Carolyn J. Ewers, Paul S. Lavery, Chris M. Roelfsema, Elizabeth A. Sinclair, Simone Strydom, Jason E. Tanner, Kor-jent van Dijk, Fiona Y. Warry, Michelle Waycott, Sam Whitehead

PII: S0141-1136(16)30103-9

DOI: 10.1016/j.marenvres.2016.06.006

Reference: MERE 4195

To appear in: Marine Environmental Research

Received Date: 31 March 2016

Revised Date: 3 June 2016

Accepted Date: 10 June 2016

Please cite this article as: York, P.H., Smith, T.M., Coles, R.G., McKenna, S.A., Connolly, R.M., Irving, A.D., Jackson, E.L., McMahon, K., Runcie, J.W., Sherman, C.D.H., Sullivan, B.K., Trevathan-Tackett, S.M., Brodersen, K.E., Carter, A.B., Ewers, C.J., Lavery, P.S., Roelfsema, C.M., Sinclair, E.A., Strydom, S., Tanner, J.E., van Dijk, K.-j., Warry, F.Y., Waycott, M., Whitehead, S., Identifying knowledge gaps in seagrass research and management: An Australian perspective, Marine Environmental Research (2016), doi: 10.1016/j.marenvres.2016.06.006.

This is a PDF file of an unedited manuscript that has been accepted for publication. As a service to our customers we are providing this early version of the manuscript. The manuscript will undergo copyediting, typesetting, and review of the resulting proof before it is published in its final form. Please note that during the production process errors may be discovered which could affect the content, and all legal disclaimers that apply to the journal pertain. 